\title{
First Record of Marine Dinoflagellate, Alexandrium tamutum (Dinophyceae) from Malaysia
}

\author{
Kon, Nyuk Fong1, Hii, Kieng Soon ${ }^{1}$, Tan, Toh Hii ${ }^{1}$, Yek, Leh Hie ${ }^{1}$, Lim, Po Teen², Leaw, Chui Pin ${ }^{1 *}$ \\ ${ }^{1}$ Institute of Biodiversity and Environmental Conservation (IBEC), University Malaysia Sarawak (UNIMAS), 94300 Kota \\ Samarahan, Sarawak, Malaysia. \\ ${ }^{2}$ Faculty of Resource Science and Technology (FRST), University Malaysia Sarawak (UNIMAS), 94300 Kota Samarahan, \\ Sarawak, Malaysia. \\ *cpleaw@ibec.unimas.my, chuipinleaw@gmail.com (corresponding author)
}

\begin{abstract}
Several species of dinoflagellates in the genus Alexandrium are known to be toxic, and have been associated with paralytic shellfish poisoning (PSP) in Malaysia. These Alexandrium species showed high morphological similarity among the toxic and non-toxic species, and detailed observation of the thecal plate's arrangement is required for precise species identification. Co-occurrence of the toxic and non-toxic species has complicated the plankton monitoring of PSP. In this study, a clone of Alexandrium species was established from plankton samples collected from Kota Belud, Sabah. The specimen was observed under epi-fluorescence microscope, and nucleotide sequences of the nuclear-encoded ribosomal RNA gene obtained. Morphologically, the clone showed relatively wide and large sixth precingular plate (6") compared to that of $A$. minutum. The posterior sulcal plate $(\mathrm{Sp})$ is similar to that of A. minutum, which is wider than long. The first apical plate $\left(1^{\prime}\right)$ is irregularly rhomboidal with a small ventral pore (vp) present on its right margin. The morphological characters resembled to the species description of A. tamutum. Phylogenetic analysis of the ITS rDNA region also revealed a monophyly of this clone with other strains of $A$. tamutum, and separating them from the $A$. minutum clade. Species-specific sequence signatures of $A$. tamutum were obtained in silico, which could be as potential oligonucleotide probe regions for species detection by using molecular tool. This represents the first report of A. tamutum found in Malaysian waters.
\end{abstract}

(Keywords: Alexandrium tamutum, A. minutum, Sabah, Malaysia, thecal plates)

\section{INTRODUCTION}

Harmful algal bloom (HAB) is a natural phenomenon due to the increase in density of phytoplankton resulted in adverse effect to the ecosystem. Contamination of biotoxins from the phytoplankton may lead to shellfish poisoning when the toxins are transferred to human via the shellfish vectors. In Malaysia, the most frequently reported seafood intoxication associated with algal toxins is paralytic shellfish poisoning (PSP) [1]. PSP is caused by the consumption of contaminated shellfish such as mussels, clams, oyster, scallop or other filter feeders $[2,3]$. The PSP toxin, collectively called Saxitoxins (STXs), is a group of toxin family that blocks the voltage gated sodium channels in mammalian nerve cells and inhibits nerve conduction, which may lead to paralysis of the neuromuscular system [4].

Bloom of the marine dinoflagellate, Pyrodinium bahamense var. compressum, in Brunei Bay and the subsequent PSP incidence in Sabah [5], was the first record of HABs and PSP in Malaysia. Whilst in Peninsular Malaysia, poisoning case was first reported in 1991 when people consumed the green mussel, Perna viridis, cultured at a mussel farm in Sebatu, Malacca. In September 2001, poisoning case including one fatality was reported from Tumpat, Kelantan, a coastal lagoon of the east coast of Peninsular Malaysia. The intoxication was due to the consumption of contaminated benthic bivalve, Polymesoda sp. (local name, 'lokan') [6].

In this study, a marine dinoflagellate from the genus Alexandrium was morphologically and molecularly characterized. Samples were obtained from Kota Belud, Sabah, Malaysia, and clonal cultures of the dinoflagellate species were established. Both preserved and field samples were observed under an epi-fluorescence microscope. Clonal cultures were further analyzed based on the nucleotide sequences of ribosomal RNA genes (rDNA). Genomic DNA was extracted, and the 
rDNA was amplified prior to sequencing. The sequences obtained were analyzed and used for phylogenetic reconstruction. Species-specific sequence signatures of A. tamutum were also obtained in silico.

\section{MATERIALS AND METHODS}

\section{Algal cultures}

Plankton samples were collected from Kota Belud, Sabah, using a $20 \mu \mathrm{m}$-mesh plankton net. Sampling was undertaken during high tide, with salinity of $\sim 30 \mathrm{psu}$. Field in situ parameter i.e. temperature, salinity and $\mathrm{pH}$ of the seawater was collected. Live samples were kept in $1 \mathrm{~L}$ bottles in cool condition and brought back to the laboratory for single-cell isolation. A portion of samples $(1 / 3)$ were preserved in acidic Lugol's solution.

Samples were sieved through a $20 \mu \mathrm{m}$-mesh sieve and back-washed to a petri dish for single-cell isolation by micropipetting technique under an IX51 inverted light microscope (Olympus, Melville, USA). Clonal cultures were established in a 96-well microplate containing filtered sterile seawater. Cultures established were grown in ES-DK medium [7], and maintained at $25 \pm 0.5^{\circ} \mathrm{C}$ under a 12:12 h light:dark photoperiod in a SHEL LAB temperature-light controlled growth chamber (SHEL LAB, USA).

\section{Species identification}

Morphological observation was performed with an epifluorescence microscopy. Identification of the species was based on cell shape and theca plate tabulation. Fixed samples were stained with $1 \%$ Calcofluor white solution (Fluka, Japan), and the nuclei were stained with SYTOX Green DNA stain (Invitrogen, Life Technologies, USA). Stained samples were observed under an Olympus IX51 epifluorescence microscope (Olympus, Melville, USA) with UV filter sets. Images were captured with a cooled CCD camera (SIS Colorview F12, Germany).

\section{DNA extraction, rDNA amplification and sequencing}

Mid-exponential growth phase cultures were harvested by centrifugation at $2,800 \mathrm{rpm}$ for $10 \mathrm{~min}$. The cell pellet was then suspended in distilled water, followed by cetyltrimethylammonium bromide (CTAB) extraction as described in $[8,9]$. Cells were lysed by adding equal volume of $2 \times \mathrm{CTAB}$ lysis buffer containing $50 \mathrm{mM}$ CTAB, $14 \mathrm{mM} \mathrm{NaCl}, 10 \mathrm{mM}$ Tris-base, $20 \mathrm{mM}$ EDTA, and $1 \%$ mecaptoethanol. The mixture was extracted with chloroform: isoamyl alcohol (C:I, 24:1), and subsequently phenol:chloroform:isoamyl alcohol (P:C:I, 25:24:1). Two volumes of absolute ethanol and 1/10 volume of $3 \mathrm{M}$ sodium acetate were added to precipitate the DNA, followed by centrifugation at $13000 \mathrm{rpm}$ for 10 min. DNA pellet was rinsed with $70 \%$ cold ethanol and then dissolved in $30 \mu \mathrm{L}$ TE buffer $(10 \mathrm{mM}$ Tris$\mathrm{HCl}, \mathrm{pH} 7.4$ and $1 \mathrm{mM}$ EDTA, pH 8.0). Genomic DNA samples were kept overnight at $4^{\circ} \mathrm{C}$ to totally dissolve the DNA before stored at $-20^{\circ} \mathrm{C}$ for further analysis.

The internal transcribed spacer region (ITS1-5.8SITS2) of rDNA was amplified by polymerase chain reaction (PCR) using the primer pair, ITS1F (5'TCGTAACAAGGTTTCCGTAGGTG-3') and ITS1R (5'ATATGCTTAAGTTCAGCGGG-3') [8]. Gene amplification was performed as described in $[8,9]$. In brief, the amplification condition is as follow: initial denaturation at $95^{\circ} \mathrm{C}$ for $5 \mathrm{~min}$, denaturation at $94^{\circ} \mathrm{C}$ for 18 seconds, annealing at $55^{\circ} \mathrm{C}$ for 18 seconds, followed by elongation at $72^{\circ} \mathrm{C}$ for $1 \mathrm{~min}$ and final elongation at $72^{\circ} \mathrm{C}$ for $7 \mathrm{~min}$. PCR products were subjected to further purification prior to DNA sequencing by the sequencing service laboratory ( $1^{\text {st }}$ Base, Selangor, Malaysia), using an ABI 377 automated sequencer (PE Applied Biosystems, Foster City, CA, USA). Sequencing was performed in both strands.

\section{Sequence analysis and taxon sampling}

Sequences were evaluated by using the Basic Local Alignment Search Tool (BLAST) program [10], and analyzed by ABI Sequence Scanner ver. 1.0 (ABI BioSystem, USA). Ambiguous bases were determined by comparing both forward and reverse strands of each strain. The reverse strands were reversed complemented by using BioEdit version 6.0.7 [11] and pairwise-aligned with the forward strands using Clustal-X [12]. These were followed by assignation according to the IUPAC nucleotide code.

Taxon sampling was achieved by blasting in the nucleotide database, GenBank, in conjunction with the National Center of Biotechnology Institute (NCBI) to acquire related sequences. The selected sequences were saved as FASTA format for further analysis.

\section{Phylogenetic analyses}

Phylogenetic analyses was performed by using Phylogenetic Analysis Using Parsimony (PAUP) ver. 
4.0b10 [13] with the maximum likelihood (ML) and maximum parsimony (MP) algorithms used to estimate the phylogeny.

For ML analysis, Modeltest ver. 3.06 [14, 15] with $\alpha$ value of 0.01 was used to identify the hierarchical likelihood ratio so that the best model of evolution can be determined. The evolutionary model was selected for the sequences data set and the ML parameters were used to reconstruct the ML tree. ML was performed by heuristic search with tree bisection-reconnection (TBR) branch swapping and 10 random additions.

MP was performed by heuristic search of 1,000 random addition and TBR branch swapping. Bootstrapping [16] was performed on both ML and MP analyses with 1,000 replication $(\mathrm{P}<0.001)$ to determine the confidence limits of tree topology using TBR branch swapping algorithm.
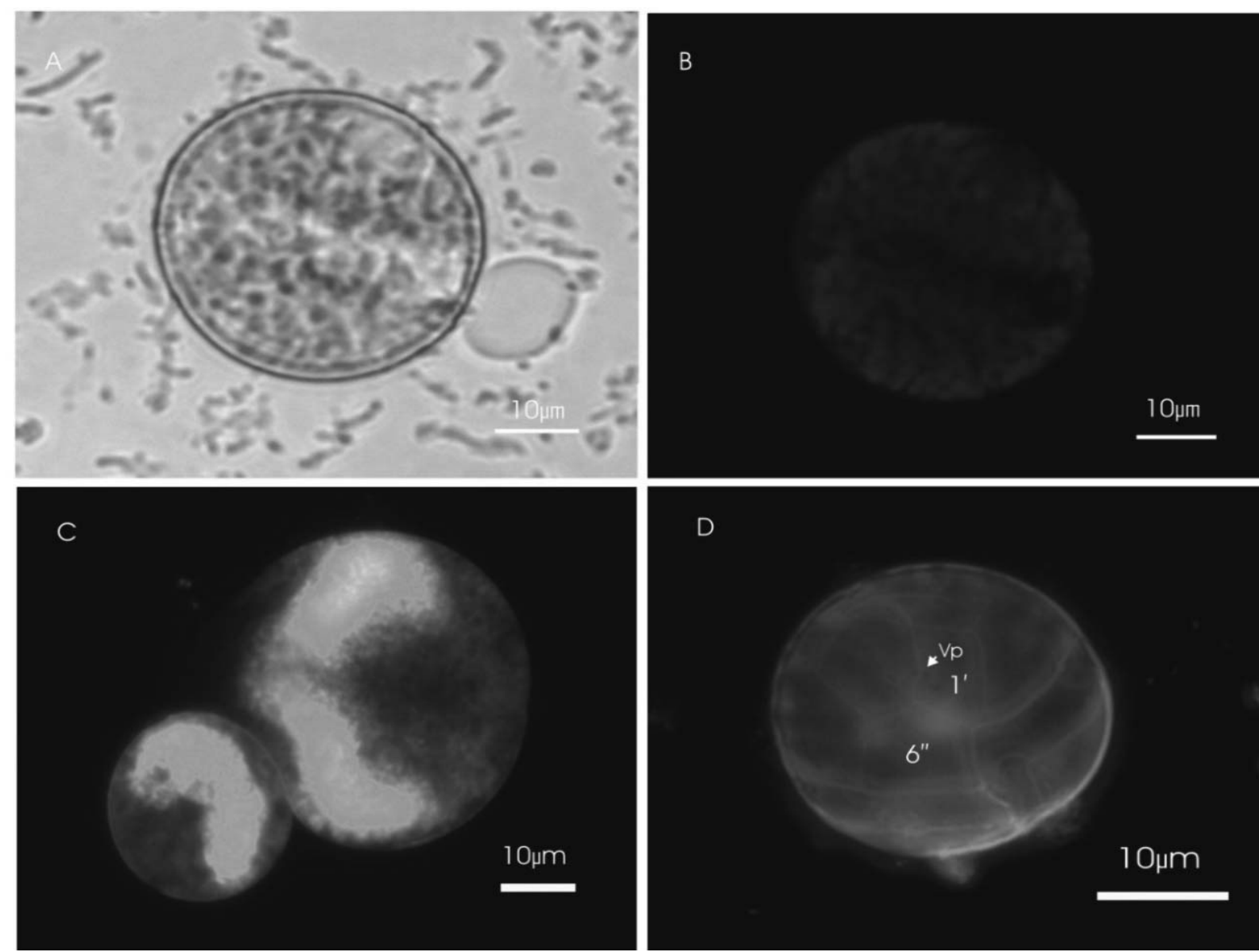

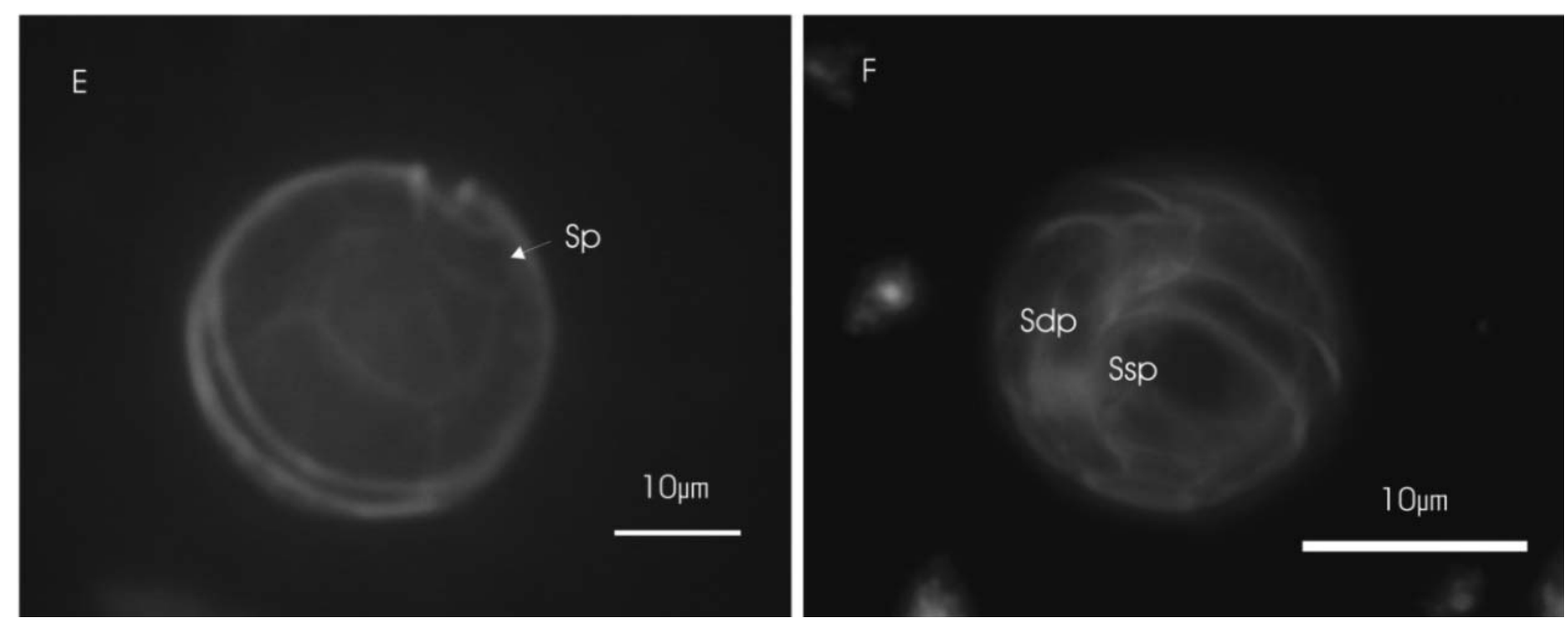

Figure 1. Alexandrium tamutum strain AuKA01 from Kota Belud, Sabah. (A) Bright field. (B) Cell showing chlorophyll pigments. (C) SYTOX green-stained cells showing the arc shaped nuclei. (D) Cell with thin thecal plates showing rhomboidal $1^{\prime}$ and wide $6^{\prime \prime}$. Note the ventral pore (vp). (E) Antapical view of cell with wider than long posterior sulcal plate (Sp). (F) Cell showing the sulcus with deep and excavated cingulum.

of the main diagnostic features used to delineate the two species [17].

\section{Morphological characterization of A. tamutum}

Cells are round and small, with 9-25 $\mu \mathrm{m}$ long and 9-33 $\mu \mathrm{m}$ wide (Figure 1). Chlorophyll pigments present indicating the cells are photosynthetic (Figure 1B). The fairly large nucleus with chromosomes that are permanently condensed can be readily seen after SYTOX Green staining (Figure 1C). The thecal plates are thin and smooth. Cingulum is deep and excavated, with its left end shifted anteriorly (Figure 1D). The first apical plate (1') is irregularly rhomboidal, with a small ventral pore (vp) present on its right margin (Figure 1D). The sixth precingular plate $\left(6^{\prime \prime}\right)$ is wider than long, and adjacent to 1' (Figure 1D). The posterior sulcal plate $(\mathrm{Sp})$ on the hypotheca is wider than long (Figure 1E). The epi-fluorescence image clearly showed the sulcal area of A. tamutum, with both right posterior sulcal plate (Sdp) and left posterior sulcal plate (Ssp) (Figure 1F).

Alexandrium tamutum resembled A. minutum in its relatively small cell size, rounded or elliptical [17]. However, large A. tamutum cells have a slightly pentagonal shape which is similar to the outline of small-sized A. tamarense [17]. Alexandrium andersoni is another small-sized species which is difficult to distinguish it from A. tamutum and A. minutum. Both $A$. andersoni and $A$. minutum are PSP toxin producers [18], but $A$. tamutum was reported as non-toxic [17].
Several Alexandrium species share similar cell outline and size ranges. Thus, it is difficult to distinguish Alexandrium species solely based on cell size and shape. Identification at species level requires detailed investigation of the pattern of their thecal plates. Alexandrium tamutum differs from A. minutum by its relatively wide and large 6 ", whereas A. minutum has narrower and smaller $6^{\prime \prime}$ [17]. The large $6^{\prime \prime}$ of $A$. tamutum is similar to that of A. tamarense [17].

Shape of the sulcal posterior plate $(\mathrm{Sp})$ has been suggested as a diagnostic character to delineate species of Alexandrium [19]. The $\mathrm{Sp}$ of A. tamutum is similar to that of $A$. minutum which is wider than long, while the Sp is longer than wide in A. tamarense. Both A. tamutum and A. minutum have rhomboidal 1' plate. However, the vp of that in A. tamutum is located in the median/ upper part of the margin [17], whilst in A. minutum it is located on the posterior end of the anterior right margin of plate $1^{\prime}$ [20].

\section{ITS rDNA phylogeny of Alexandrium}

The ITS region of rDNA of A. tamutum was successfully amplified for the strain AuKA01. Blast search revealed an e-value of 0.0 with a total of six hits to A. tamutum in the nucleotide database of GenBank (NCBI). Closely related species of $A$. tamutum were included in the taxon sampling; they are A. affine, A. andersoni A. catenella, A. minutum, , A. ostenfeldii, A. peruvianum A. tamarense and $A$. tamiyavanichii (Table1). Pyrodinium bahamense var. compressum was used as the outgroup. 
Table 1. Sequences of ITS region retrieved from NCBI nucleotide database with species, strain and accession.

\begin{tabular}{|c|c|c|}
\hline Species & Strain & Location \\
\hline \multirow[t]{2}{*}{ Alexandrium affine } & $\mathrm{AC}-1$ & China \\
\hline & AS-1 & China \\
\hline A. andersoni & CCMP 1718 & Massachusetts, USA \\
\hline \multirow[t]{3}{*}{ A. catenella } & PE01 & Southern Chile \\
\hline & A4 & Daya Bay, China \\
\hline & AD1 & East China Sea, China \\
\hline \multirow[t]{4}{*}{ A. minutum } & CBA64 & Catalan Sea, Spain \\
\hline & AMITA & Trieste, Italy \\
\hline & Palmiral & Catalan Sea, Spain \\
\hline & $\mathrm{CBA} 28$ & Tyrrhenian Sea, Italy \\
\hline \multirow[t]{3}{*}{ A. ostenfeldii } & AOFUN0905 & Hokkaido, Japan \\
\hline & AOFUN0904 & Hokkaido, Japan \\
\hline & ASBH01 & China \\
\hline \multirow[t]{2}{*}{ A. peruvianum } & IEO-VGOAMD12 & Catalan Sea, Spain \\
\hline & IEO-VGOAM10 & Catalan Sea, Spain \\
\hline \multirow[t]{2}{*}{ A. tamarense } & 04-197-30 & Scotland, United Kingdom \\
\hline & S06-010-01 & Scotland, United Kingdom \\
\hline \multirow[t]{3}{*}{ A. tamiyavanichii } & A1PSA & Porto Seguro, Brazil \\
\hline & B2PSA & Porto Seguro, Brazil \\
\hline & PSII & Porto Seguro, Brazil \\
\hline \multirow[t]{6}{*}{ A. tamutum } & IEO-VGO616 & Catalan Sea, Spain \\
\hline & IEO-VGO617 & Catalan Sea, Spain \\
\hline & IEO-VGO615 & Catalan Sea, Spain \\
\hline & AL2T & - \\
\hline & LBM-A5 & North West Adriatic Sea, Italy \\
\hline & IEO-VGO662 & Tyrrhenian Sea, Italy \\
\hline
\end{tabular}

The resulting BI tree showed that AuKA01 strain obtained in this study was clustered together with other A. tamutum from GenBank (AM236857, AM236858, AM236859, AM236860, AM238452 and EU707497) (Figure 2). This further supported the species identification of strain AuKA01 as A. tamutum. The clade formed a sister group with A. minutum group (FR668134, FR668136, FR668140, FR668142). The molecular phylogenetic inference supported the morphological observation that $A$. tamutum was a sister taxon to A. minutum.

The MP analysis revealed 333 parsimony-informative characters, resulted in one parsimonious tree with a tree length of 1,039 evolutionary steps, with the parsimony indices of consistency index $(\mathrm{CI})=0.7036$, homoplasy index $(\mathrm{HI})=0.2964$, retention index $(\mathrm{RI})=0.8229$, and rescaled consistency index $(\mathrm{RC})=0.5790$.

Bootstrap supports of the monophyly of A. tamutum were relatively high with MP, ML bootstraps of $81 \%$ and $78 \%$ respectively, and $\mathrm{BI}$ posterior probability $(\mathrm{PP})$ of 1.0. The A. minutum clade was also supported by $100 \%$ for MP, $96 \%$ for ML and 1.0 for BI.

Although A. tamutum is closely related morphologically to A. minutum, the results of phylogenetic inferences 


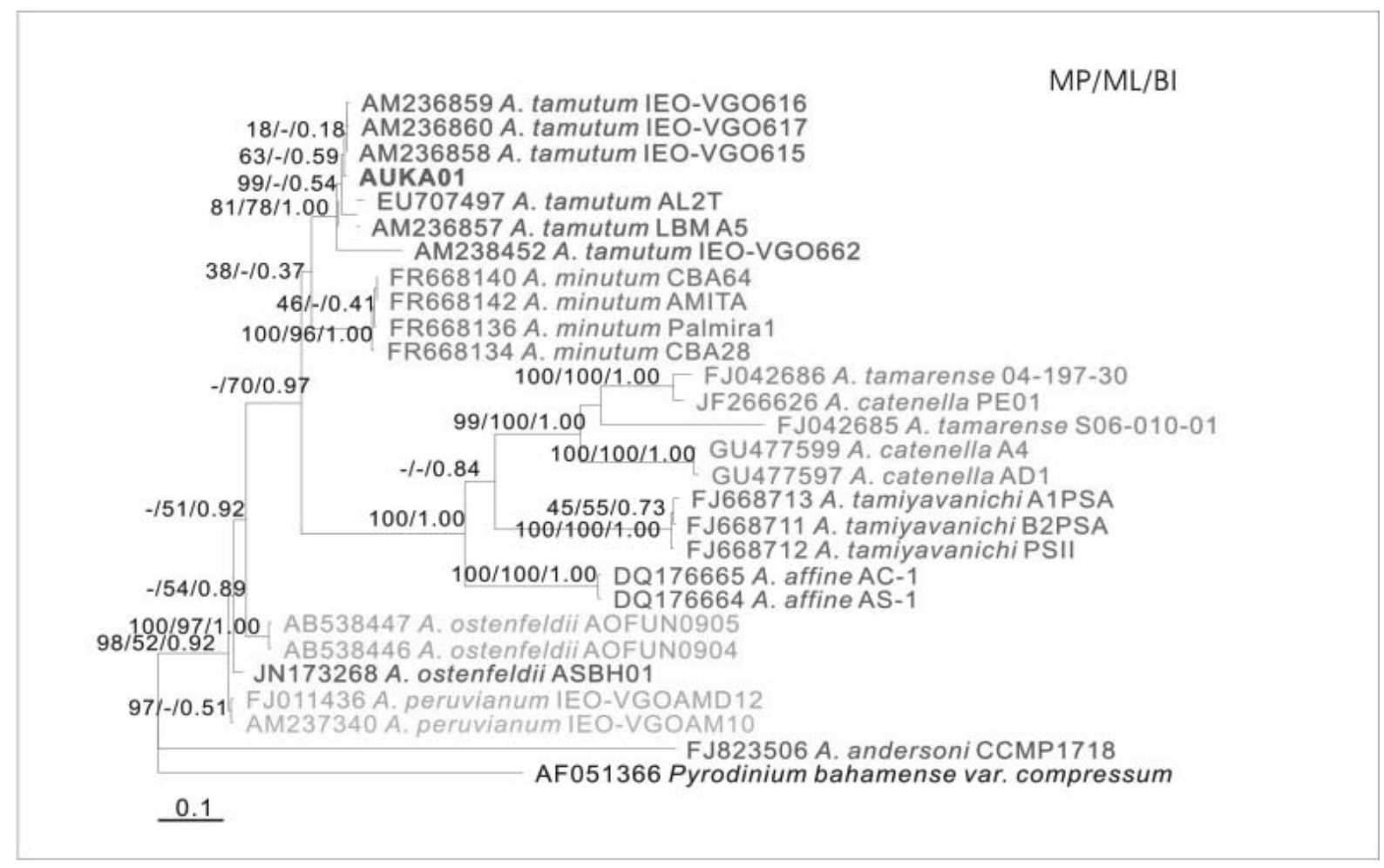

Figure 2. Phylogenetic tree of Alexandrium species derived from Bayesian analysis (BI) of ITS sequences. Alexandrium tamutum from Kota Belud, Sabah used in this study are in boldface. Bootstrap supports of MP/ML/BI are shown at the internal nodes. Scare bar $=0.1$ substitution per site.

strongly supported the split of $A$. tamutum as a single clade, while A. minutum formed another clade (Figure 2).

\section{Sequence signature}

The ITS sequence of A. tamutum was aligned with ITS sequences of other Alexandrium species retrieved from the GenBank to search for the signature regions.
By using ARB program, several regions of sequences with nucleotides length of $25 \mathrm{bp}$ and $100 \%$ hits were identified. These regions were identified as speciesspecific to A. tamutum based on the nucleotide polymorphism to the non-target species. Table 2 shows the E-value and number of hits of the nblast search result. Three signature regions were proposed as the DNA signature of A. tamutum (Figure 3).

Table 2. nBlast search of signature regions revealed the respective e-value and the number of hits

\begin{tabular}{llll}
\hline Signature & $\begin{array}{l}\text { Uppermost Blastn hit against NCBI } \\
\text { nr-database }\end{array}$ & e-value & Number of hits \\
\hline AGGGUGGCAUGGCUUGCAAUAGCAA & A. tamutum & 2e-04 & 6 \\
AUGCUGCUGCAUUGGACACACGCGC & A. tamutum & $2 \mathrm{e}-04$ & 5 \\
AUUUGCUCGAGGGUGGCAUGGCUUG & A. tamutum & 2e-04 & 5 \\
\hline
\end{tabular}


A

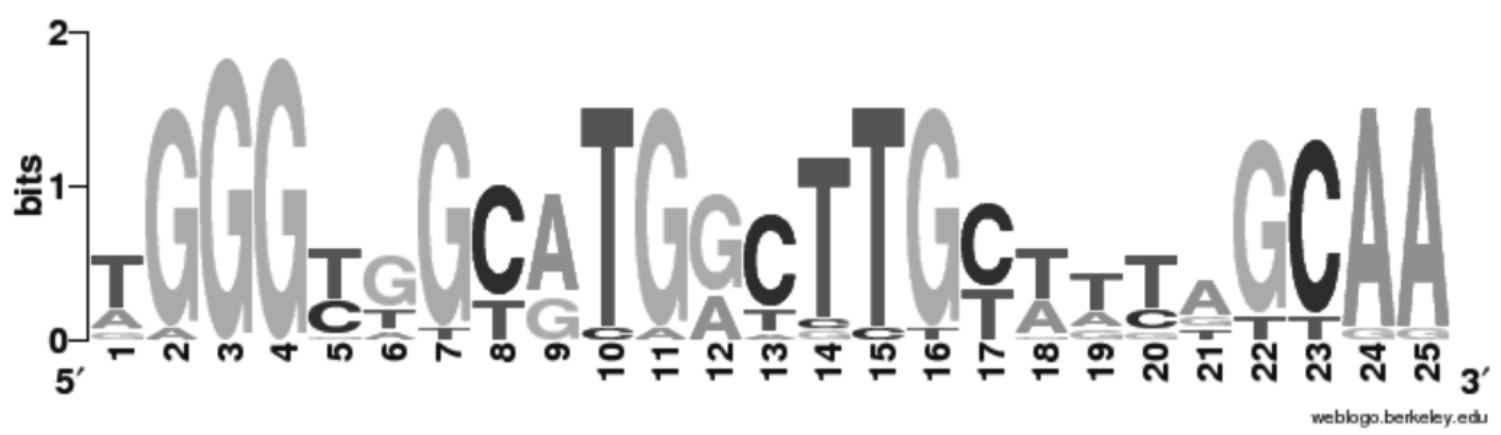

B

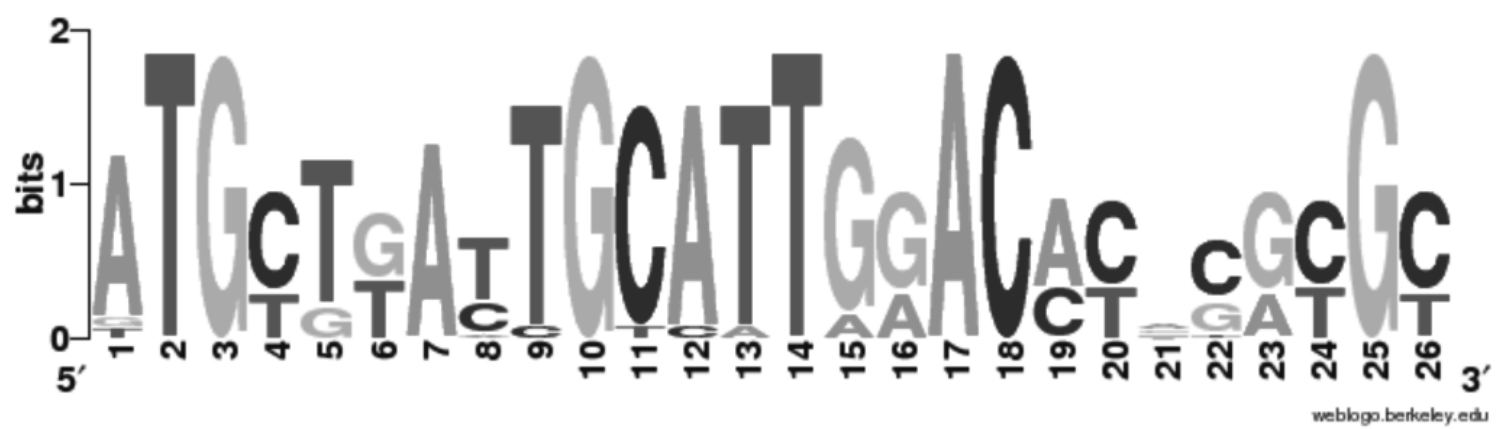

C

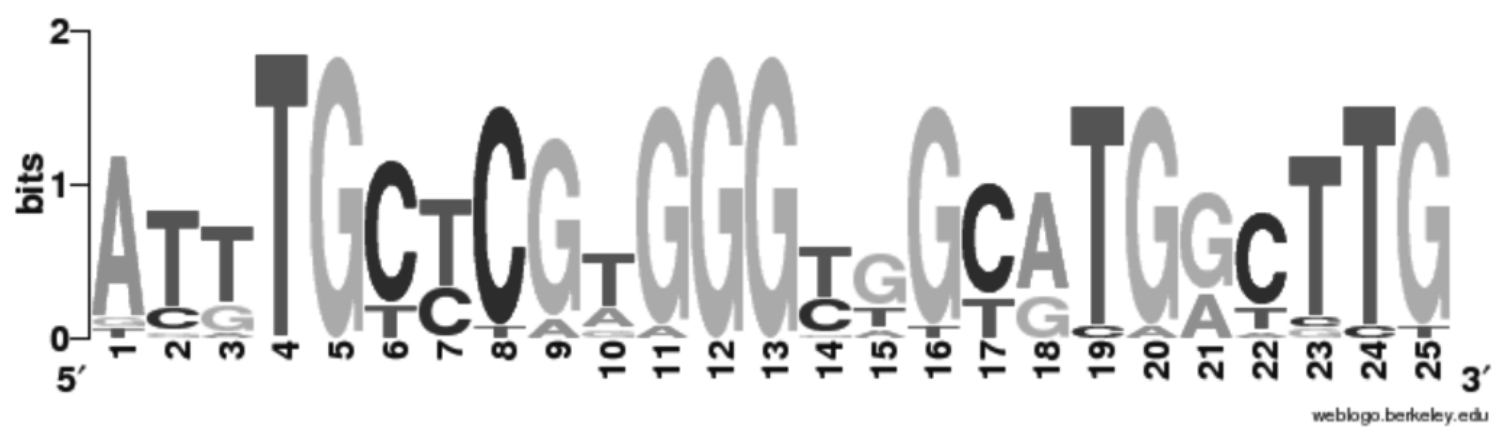

Figure 3. Three possible sequence logos of signature region of $A$. tamutum predicted in this study

\section{CONCLUSION}

Culture of Alexandrium from Kota Belud, Sabah was identified and designated as Alexandrium tamutum based on the rhomboidal first apical plate $\left(1^{\prime}\right)$, wide sixth precingular plate $\left(6^{\prime \prime}\right)$ and wide posterior sulcal plate $(\mathrm{Sp})$. The phylogenetic analyses also supported the species identity based on the evidence of monophyly of taxa identified as A. tamutum. This represents the first report of $A$. tamutum found in the Malaysian waters. Species-specific sequence signatures of $A$. tamutum were obtained in silico. The species-specific sequence signatures of $A$. tamutum obtained in this study can be used to develop molecular probe for rapid detection of the species.

\section{REFERENCES}

1. Lim P. T., Leaw C. P., Usup G. and Ahmad A. (2002). Probable toxin producer responsible for the first occurrence of paralytic shellfish poisoning on the east coast of peninsula Malaysia. Malaysian Applied Biology 31(2): 29-35. 
2. Shumway S. (1990). A review of the effect of algal blooms on shellfish and aquaculture. Journal of World Aquaculture Society 21: 65-104.

3. Shumway S. E., Sherman-Caswell S. and Hurst J. W. (1988). Paralytic shellfish poisoning in Maine: Monitoring a monster. Journal of Shellfish Research 7: 643-652.

4. Doucette G. J., Logan M. L., Ramsdell J. S. and Dolah F. M. V. (1997). Development and preliminary validation of a microtiter plate-based receptor binding assay for paralytic shellfish poisoning toxins. Toxicon 35: 625-636.

5. Roy R. N. (1976). Red tide and outbreak of paralytic shellfish poisoning in Sabah. Medical Journal of Malaysia 31(3): 247-251.

6. Lim P. T., Leaw C. P. and Usup, G. (2004). First incidence of paralytic shellfish poisoning on the east coast of Peninsular Malaysia. In Phang, S. M., Chong, V. C., Ho, S. S., Mokhtar, N., Ooi, J. L. S. (eds.) Marine Science into New Millennium: New perspectives and challenges. University of Malaya Maritime Research Centre, Kuala Lumpur, pp. 661-667

7. Kokinos J. P. and Anderson D. M. (1995). Morphological development of resting cysts in cultures of the marine dinoflagellate Linguladinium polyedrum (= L. machaerophorum). Palynology 19: $143-166$.

8. Leaw C. P., Lim P. T., Ahmad A. and Usup G. (2001). Genetic diversity of Ostreopsis ovata (Dinophyceae) from Malaysia. Marine Biotechnology 3(3): 246-255.

9. Leaw C. P., Lim P. T., Ng B. K., Cheah M. Y., Ahmad A. and Usup G. (2005). Phylogenetic analysis of Alexandrium species and Pyrodinium bahamense (Dinophyceae) based on theca morphology and nuclear ribosomal gene sequence. Phycologia 44: 550-565.

10. Altschul S. F., Gish W., Miller W., Myer E. W. and Lipman D. J. (1990). Basic local alignment search tool. Journal of Molecular Biology 215: 403-410.

11. Hall T. A. (1999). BioEdit: A user-friendly biological sequence alignment editor and analysis program for Windows 95/98/NT. Nucleic Acids Symposium Series 41: 95-98.

12. Thompson J. D., Gibson T. J., Plewniak F., Jeanmougin F. and Higgins D. G. (1997). The CLUSTAL $\mathrm{X}$ windows interface: Flexible strategies for multiple sequence alignment aided by quality analysis tools. Nucleic Acids Research 24: 4876-4882.

13. Swofford D. L. (2000). PAUP*: phylogenetic analysis using parsimony (* and other methods).
Version 4.0b10. Sinauer Associates, Sunderland, Massachusetts, USA.

14. Posada D. and Crandall K. A. (1998). Modeltest: Testing the model of DNA substitution. Bioinformatics 14: 817-818.

15. Posada D. and Crandall K. A. (2001). Selecting the best-fit model of nucleotide substitution. Systematic Biology 50: 580-601.

16. Felsenstein J. (1985). Confidence limits on phylogenies: An approach using the bootstrap. Evolution 39: 783-791.

17. Montresor M., John U., Beran A. and Medlin L. (2004). Alexandrium tamutum sp. nov. (Dinophyceae): A new, non-toxic species in the genus Alexandrium. Journal of Phycology 40 (2): 398-411.

18. Ciminiello P., Fattorusso E., Fiorino M. and Montresor, M. (2000). Saxitoxin and neosaxitoxin as toxic principles of Alexandrium andersoni (Dinophyceae) from the Gulf of Naples, Italy. Toxicon 38: 1871-1877.

19. Usup G., Leaw C. P., Ahmad A. and Lim P. T. (2002). Phylogenetic relationship of Alexandrum tamayavanichii (Dinophyceae) to other Alexandrium species based on ribosomal RNA gene sequences. Harmful Algae 1: 59-68.

20. Balech E. (1995). The Genus Alexandrium halim (Dinoflagellata). Sherkin Island Marine Station, Cork, Ireland.

21. Schneider T. D and Stephens R. M. (1990). Sequence logos: A new way to display consensus sequences. Nucleic Acids Research 18(20): 60976100. 